\title{
BUDAYA ORGANISASI DAN KEPUASAN KERJA DENGAN MOTIVASI KERJA ANGGOTA SATLANTAS
}

\author{
Ferdyanzah Wira Adhiyana ${ }^{1(D)}$, Rr. Amanda Pasca Rini ${ }^{2}$, Sahat Saragih ${ }^{3}$ \\ ${ }^{1,2,3}$ Fakultas Psikologi, Universitas 17 Agustus 1945 Surabaya, Surabaya, Jawa Timur, Indonesia
}

\begin{abstract}
Work motivation in the organization has a close relationship with the willingness to complete the work properly. Such will is a form of encouragement that creates a passion for work. Positive work spirit is a useful factor in improving the ability to work. This research was conducted on member of Traffic Unit at Police of Sidoarjo with number of subjects of this study was 89 people. All subjects have long worked in the Traffic Police Sidoarjo unit at least 1 year with the rank of Bripda up to Aiptu. There is significant relation between organization culture and work statisfication with work motivation $\mathrm{F}=38,691 ; \mathrm{p}=0,000)$ on member of traffic unit at police of Sidoarjo.
\end{abstract}

Keywords : Organisation Culture, Work Statisfication, Work Motivation

\begin{abstract}
ABSTRAK
Motivasi kerja dalam organisasi mempunyai hubungan yang erat dengan kemauan menyelesaikan pekerjan dengan baik. Kemauan tersebut merupakan bentuk suatu dorongan yang menciptakan semangat dalam bekerja. Semangat kerja yang positif dapat menjadi faktor yang berguna meningkatkan kemauan dalam bekerja. Penelitian ini dilakukan pada anggota Satuan lalu lintas di Polresta Sidoarjo dengan jumlah subjek penelitian ini adalah 89 orang. Seluruh subjek telah lama bekerja di bagian Satuan lalu lintas Polresta Sidoarjo minimal 1 tahun dengan pangkat Bripda sampai dengan Aiptu. Hasil penelitian menunjukan ada hubungan yang signifikan antara budaya organisasi dan kepuasan kerja dengan motivasi kerja $(\mathrm{F}=38,691 ; \mathrm{p}=$ 0,000) anggota satlantas Polresta Sidoarjo.
\end{abstract}

Kata Kunci: Budaya organisasi, Kepuasan kerja, Motivasi kerja, Polisi Lalu lintas 
Psikologia (Jurnal Psikologi), Vol 2 (2), July 2017, 81-92

ISSN 2338-8595 (print), ISSN 2541-2299 (online)

Journal Homepage: http://ojs.umsida.ac.id/index.php/psikologia

DOI Link: 10.21070/psikologia.v2i2.1497

\section{PENDAHULUAN}

Kepolisian Republik Indonesia khususnya Satlantas sering kali bersentuhan langsung dengan masyarakat saat memberikan pelayanan, oleh karena itu pihak Kepolisian harus mampu memberikan pelayanan secara profesional dan memegang kode etik sehingga akan menciptakan kesan yang baik di mata masyarakat

Polri di bidang lalu lintas terus menerus meningkatkan berbagai pelayanannya mulai dari SIM keliling, SIM Corner, SIM Online dan sekarang yang terbaru ialah E-tilang. Peningkatan pelayanan masyarakat yang terus dilakukan oleh Polri, apabila tidak di dukung anggota Polantas yang kompeten tentu tidak akan memberikan dampak yang signifikan terhadap program atau rencana kerja yang dijalankan.

Menurut Kabidhumas Polda Jatim Kombespol Hilman Thayib mengakui bahwa, jumlah polisi yang melanggar aturan masih banyak. Namun, sebagian besar pelanggaran yang dilakukan masih dalam batas pelanggaran disiplin. Misalnya membolos, tidak mengikuti kegiatan atau terlambat mengikuti apel, perizinan senjata telah lama mati dan tidak segera diperbaharui, ujarnya. Pelanggaran macam itu, lanjut Hilman, bagi sebagian masyarakat dipandang sebagai pelanggaran ringan.
Namun, bagi polisi, pelanggaran tetap pelanggaran. Mereka akan tetap disanksi jika terbukti. Salah satu sanksinya adalah kurungan maksimal 21 hari di Tahanan Polisi.(http://www.surabayapagi.com/read/7 7990/2012/03/17/125_Polisi_Bermasalah,_ Kapolda_Marah.html diakses pada 8 Mei 2017)

Permasalahan diatas menunjukan bahwa bentuk pelanggaran yang dilakukan anggota Polri cukup tinggi. Perilaku anggota yang dapat diamati oleh masyarakat seperti datang terlambat saat apel, tidak tampak di tempat kerja saat menjalankan tugas, pengaturan lalu lintas di lapangan tidak dilakukan hingga tuntas, pelayanan pengurusan surat terlihat santai, nampak seperti tidak memiliki semangat melakukan tugasnya.

Motivasi kerja anggota lalu lintas yang rendah dapat terlihat secara langsung oleh masyarakat karena anggota lalu lintas berhadapan secara langsung dengan masyarakat, berbeda dengan satuan kerja lain yang tidak bersentuhan secara langsung dengan masyarakat. Rendahnya motivasi kerja tersebut berdampak buruk terhadap citra Polri di masyarakat.

Motivasi kerja menurut Winardi (2002) merupakan suatu hasrat seseorang untuk mengambil suatu keputusan, bertindak dan 
Psikologia (Jurnal Psikologi), Vol 2 (2), July 2017, 81-92

ISSN 2338-8595 (print), ISSN 2541-2299 (online)

Journal Homepage: http://ojs.umsida.ac.id/index.php/psikologia

DOI Link: 10.21070/psikologia.v2i2.1497

menggunakan semua kemampuan yang dimilikinya mulai dari psikis, sosial, dan kekuatan fisiknya untuk memenuhi hasrat dalam dirinya, keinginan seseorang dalam melakukan sesuatu kegiatan atau pekerjaan secara aktif berkemauan mencurahkan waktu maupun biaya demi tercapainya tujuan yang diinginkan.

Terkait budaya organisasi lebih detailnya dapat dikatakan bahwa budaya organisasi ditentukan oleh kondisi kerja tim, kepemimpinan dan karakteristik organisasi serta proses administrasi yang diyakini dan dilakukan terus menerus (Koesmono, 2005). Suatu organisasi perlu memiliki suatu arah untuk dapat mencapai tujuan atau berjalan sesuai dengan visi misinya, ditentukan oleh hal-hal yang kasat mata, seperti struktur organisasi, laporan keuangan, aset bergerak dan tidak bergerak seperti gedung dan sebagainya, melainkan dapat ditentukan juga oleh hal-hal yang tidak kasat mata (Moeljono, 2003).

Robbins (2003) memiliki pandangan mengenai kepuasan kerja yang didefinisikan sebagai suatu bentuk sikap seseorang terhadap pekerjaannya, mengenai banyaknya imbalan yang diperoleh dengan banyaknya yang diyakini seharusnya didapatkan. Ada berbagai cara yang dapat dilakukan untuk meningkatkan kepuasan kerja karyawan, salah satunya dengan memenuhi kebutuhankebutuhan karyawan agar meningkatkan motivasi kerja mereka (Siagian, 1997).

Dalam rangka meningkatkan citra Polri di mata masyarakat khusunya Polantas maka perlu dilakukan kajian mendalam di Polresta Sidoarjo untuk dlakukan penelitian dalam bidang tersebut. Berdasarkan uraian di atas motivasi kerja Polri menjadi suatu hal yang penting sebagai daya ungkit untuk meningkatkan diri. Motivasi kerja tersebut apabila tidak diperhatikan dapat memperburuk citra polisi khususnya bidang lalu lintas.

\section{Tujuan Penelitian}

Tujuan penelitian ini adalah :

1. Menguji dan menganalisa apakah ada hubungan antara budaya organisasi dan kepuasan kerja dengan motivasi kerja anggota Satlantas di Polresta Sidoarjo.

2. Menguji dan menganalisa apakah ada hubungan positif antara budaya organisasi dengan motivasi kerja anggota Satlantas di Polresta Sidoarjo

3. Menguji dan menganalisa apakah ada hubungan positif antara kepuasan kerja dengan motivasi kerja anggota Satlantas di Polresta Sidoarjo 
Psikologia (Jurnal Psikologi), Vol 2 (2), July 2017, 81-92 ISSN 2338-8595 (print), ISSN 2541-2299 (online) Journal Homepage: http://ojs.umsida.ac.id/index.php/psikologia DOI Link: 10.21070/psikologia.v2i2.1497

\section{Motivasi kerja}

Motivasi merupakan suatu hasrat yang berasal dari dalam pribadi seseorang dengan dipengaruhi oleh faktor ekternal maupun internal yang mampu memberikan keinginan individu melakukan suatu tugas atau aktifitas tertentu untuk mendukung tujuan organisasi. (As'ad, 2004; Handoko, 1997)

Motivasi merupakan suatu proses dalam diri individu disaat kebutuhan-kebutuhan seseorang dapat menjadi pendorong yang memunculkan semangat, keinginan atau dorongan kerja untuk melakukan serangkaian kegiatan dan aktifitas yang diarahkan untuk tercapainya tujuan tertentu, sehingga motivasi kerja dapat dikaitkan sebagai pemicu semangat kerja. (Anoraga, 2006; Munandar, 2001).

\section{Indikator Motivasi kerja}

Indikator-indikator untuk mengukur motivasi kerja menurut Syahyuti (2010):

1. Dorongan mencapai tujuan : Seseorang yang mempunyai motivasi kerja yang tinggi maka dalam dirinya mempunyai dorongan yang kuat untuk mencapai kinerja yang maksimal, yang nantinya akan berpengaruh terhadap tujuan dari suatu perusahaan atau instansi.

2. Semangat kerja : Semangat kerja yang baik apabila dorongan tersebut menimbulkan kesenangan yang membuat seseorang untuk lebih giat bekerja dan lebih rajin serta konsisten.

3. Inisiatif dan kreatifitas : Inisiatif diartikan sebagai kekuatan atau kemampuan seseorang karyawan atau pegawai untuk memulai atau meneruskan suatu pekerjaan dengan penuh energi tanpa ada dorongan dari orang lain atau atas kehendak sendiri, sedangkan kreatifitas adalah kemampuan seseorang pegawai atau karyawan untuk menemukan atau membuat sesuatu yang baru dalam wujud yang sebelumnya belum diketahui atau dikenal.

4. Rasa tanggung jawab : Individu yang mempunyai motivasi kerja memiliki perasaan bertanggung jawab terhadap pekerjaan yang mereka lakukan sehingga pekerjaan tersebut mereka selesaikan secepatnya.

\section{Budaya Organisasi}

Budaya organisasi merupakan suatu sistem mengenai makna bersama terhadap suatu sistem nilai yang dipercayai, dimiliki dan dilakukan dalam suatu organisasi. Hal tersebut yang menjadi dasar dari pengambilan suatu keputusan untuk bertindak dan membedakan organisasi satu dengan organisasi (Mas'ud, 2004; Robbins, 1996) 
Psikologia (Jurnal Psikologi), Vol 2 (2), July 2017, 81-92 ISSN 2338-8595 (print), ISSN 2541-2299 (online) Journal Homepage: http://ojs.umsida.ac.id/index.php/psikologia DOI Link: 10.21070/psikologia.v2i2.1497

Menurut Buchanan dan Huczyski, dalam Koesmono (2005) budaya organisasi dalam suatu organisasi dapat berupa elemen-elemen yang terkandung nilai-nilai, kepercayaankepercayaan, sikap-sikap, pendapatpendapat, dan norma-norma. Keutamaan budaya organisasi ialah sebagai pengendali dan memberikan arah untuk membentuk sikap maupun perilaku manusia yang terlibat dalam suatu aktifitas di dalam organisasi (Molenaar, 2002).

\section{Indikator Budaya Organisasi}

Menurut Robbins (2005) indikator budaya organisasi di klasifikasikan menjadi tujuh indikasi yang dapat menangkap inti dari budaya yang terjadi dalam suatu organisasi, yaitu :

1. Inovasi dan keberanian mengambil risiko. Sejauh mana kemampuan suatu individu atau karyawan yang terdorong untuk menemukan atau membuat sesuatu hal yang baru dan memiliki keberanian dalam mengambil resiko.

2. Perhatian pada hal-hal rinci. Sejauh mana kesediaan atau kerelaan individu dalam melakukan atau menjalankan aktifitas kerjanya secara presisi, analisis, dan memiliki kemuan mencermati pada hal-hal yang terperinci.

3. Orientasi hasil. Hal ini merupakan dimana manajemen lebih menitikberatkan pada hasil daripada pada cara dan proses yang digunakan untuk mencapai hasil tersebut.

4. Orientasi orang. Sejauh mana keputusan dan kebijakan yang diambil oleh manajemen telah mempertimbangkan dampak dari keputusan yang disepakati tersebut.

5. Orientasi tim. Sejauh mana kegiatan kerja dan aktifitas kerja di organisasi dilakukan dengan mengutamakan kerja tim dibanding pada indvidu.

6. Keagresifan. Sejauh mana individu di dalam organisasi lebih bersikap aktif dan kompetitif dibanding bersantai.

7. Stabilitas. Sejauh mana kegiatan yang dilakukan atau disetujui oleh organisasi lebih menekankan dan mempertahankan status quo dengan membandingkannya pada perkembangan organisasi.

\section{Kepuasan Kerja}

Kepuasan kerja dapat menjadi suatu cermin dari perasaan seseorang yang berada dalam suatu organisasi terhadap pekerjaannya. Robbins (2003) menjelaskan lebih dalam mengenai kepuasan kerja adalah perwujudan sikap seseorang terhadap pekerjaannya, mengenai perbandingan imbalan yang diterima dengan banyaknya yang diyakini seharusnya ditrima. 
Psikologia (Jurnal Psikologi), Vol 2 (2), July 2017, 81-92

ISSN 2338-8595 (print), ISSN 2541-2299 (online)

Journal Homepage: http://ojs.umsida.ac.id/index.php/psikologia

DOI Link: 10.21070/psikologia.v2i2.1497

Crossman (2003) menjelaskan bahwa kepuasan kerja didefinisikan sebagai bentuk emosi yang positif dari perasaan senang karyawan yang berasal dari pekerjaan sebagai bentuk sikap afektif dan kognitif dari karyawan tentang aspek-aspek dalam pekerjaanya

Kepuasan kerja memiliki hubungan erat dengan keadaan emosional individu yang dimanifestasikan berupa perasaan menyenangkan atau sebaliknya tergantung persepsi karyawan memandang positif atau negative pekerjaannya (Jewell dan Siegall, 1998).

\section{Indikator Kepuasan kerja}

Robbins (2008) menjelaskan bahwa kepuasan kerja seseorang dapat diukur melalui lima indikator yang diuraikan lebih lanjut sebagai berikut:

1. Kepuasan dengan gaji, yaitu upah yang didapatkan oleh seseorang telah sesuai dengan upaya/usaha yang sudah dilakukan dan sesuai dengan upah yang semestinya diterima oleh orang lain pada posisi kerja yang sama.

2. Kepuasan dengan pekerjaan itu sendiri, yaitu dimana pekerjaan yang dilakukan dapat memberikan kesempatan seseorang untuk mempelajari dan memperoleh suatu tanggung jawab dalam suatu tugas tertentu dan tantangan untuk pekerjaan yang menarik.

3. Kepuasan dengan promosi, yaitu memberikan kesempatan bagi setiap karyawan dengan kesempatan yang sama agar dapat meraih atau mencapai jabatan tertentu yang lebih tinggi.

4. Kepuasan dengan sikap atasan, yaitu sejauh mana sikap atasan mau memberikan kesempatan berupa bantuan secara teknis dan mendukung pekerjaan bawahan.

5. Kepuasan dengan rekan kerja, yaitu rekan kerja dapat memberikan bantuan secara teknis dan mampu secara sosial menjalin hubungan baik

\section{Hubungan motivasi kerja, budaya organisasi dan kepuasan kerja}

Harris dan Mossholder (1996) menjelaskan bahwa, motivasi kerja dipengaruhi oleh budaya organisasi. Organisasi perlu mensosialisasikan nilainilai yang berlaku kepada seluruh karyawan agar nilai-nilai tersebut dapat terus melekat pada setiap anggota organisasi, sehingga budaya organisasi ini akan memberikan dampak pada perilaku dan sikap setiap anggota organisasi telah sesuai dengan nilai-nilai yang dianut. Budaya organisasi yang baik mampu 
Psikologia (Jurnal Psikologi), Vol 2 (2), July 2017, 81-92

ISSN 2338-8595 (print), ISSN 2541-2299 (online)

Journal Homepage: http://ojs.umsida.ac.id/index.php/psikologia

DOI Link: 10.21070/psikologia.v2i2.1497

menciptakan hasrat individu untuk bekerja sama dan terus melakukan perbaikan demi mencapai tujuan organisasi.

Apabila karyawan merasa sesuai dengan budaya organisasi di dalam suatu perusahaan tersebut maka akan meningkatkan motivasi kerja karyawan tersebut (Robbins, 2002).

Hal tersebut tentu berlaku sama dengan keadaan di Kepolisian, demi mewujudkan tercapainya tujuan Polri, maka seluruh sumber daya yang dimiliki harus dapat berfungsi secara optimal. Salah satunya adalah sumber daya manusia, karena manusia merupakan suatu aset dalam organisasi yang memegang peran penting dalam menentukan keberhasilan sebuah organisasi

Polri, dalam mengoptimalkan sumber daya manusia yang tersedia, perlu mendorong anggotanya untuk berupaya lebih giat bekerja dan memahami pentingnya tujuan organisasi. Ada berbagai cara yang dapat dilakukan untuk meningkatkan kepuasan kerja karyawan, salah satunya dengan memenuhi kebutuhan-kebutuhan karyawan agar meningkatkan motivasi kerja mereka (Siagian, 1997).

\section{Hipotesis}

Bertolak dari kajian teori tersebut, hipotesis yang dirumuskan adalah sebagai berikut:

1. Ada hubungan positif antara budaya organisasi dan kepuasan kerja dengan motivasi kerja anggota Satlantas di Polresta Sidoarjo

2. Ada hubungan positif antara budaya organisasi dengan motivasi kerja anggota Satlantas di Polresta Sidoarjo

3. Ada hubungan positif antara kepuasan kerja dengan motivasi kerja anggota Satlantas di Polresta Sidoarjo

\section{METODE PENELITIAN}

\section{Rancangan Penelitian}

Penelitian ini menggunakan pendekatan kuantitatif. Pendekatan kuantitatif adalah suatu penelitian yang lebih banyak menggunakan angka-angka dan tabel, mulai dari teknik pengumpulan data, penafsiran terhadap data yang diperoleh dari sampel penelitian, serta penampilan dari hasil penelitian (Arikunto, S, 2006).

\section{Subjek Penelitian}

Subjek penelitian dilakukan secara purposive, yaitu anggota Satlantas Polresta Sidoarjo yang memiliki pangkat minimal Bripda sampai dengan Aiptu dan bergabung dengan Satlantas Polresta Sidoarjo minimal 
Psikologia (Jurnal Psikologi), Vol 2 (2), July 2017, 81-92

ISSN 2338-8595 (print), ISSN 2541-2299 (online) Journal Homepage: http://ojs.umsida.ac.id/index.php/psikologia

DOI Link: 10.21070/psikologia.v2i2.1497

1 Tahun dengan tingkat pendidikan minimal

SMA sederajat. Setelah dilakukan pemilahan diperoleh subjek penelitian sebanyak 89 subjek.

\section{Prosedur dan Analisa Data Penelitian}

Menyusun alat ukur yang bisa diterapkan pada subjek penelitian. Selanjutnya untuk menguji kehandalan dari suatu instrument penelitian maka dilakukan uji coba terlebih dahulu. Kemudian dilakukan pengambilan data pada anggota Satlantas Polresta Sidoarjo. Hasil pengambilan data yang telah diperoleh dapat diinput, dan diolah dengan menggunakan Program SPSS for Windows. Analisis yang digurnakan yaitu analisis parametrik Regresi linear berganda. Hasil dari analisis ini mendapatkan suatu hubungan antar variabel.

\section{HASIL DAN PEMBAHASAN}

Berdasarkan hasil penelitian didapatkan data-data dari lokasi penelitian yang akan diuraikan sebagai berikut :

Tabel 1. Hasil Uji Hipotesis Pertama

\begin{tabular}{|r|r|r|r|r|r|}
\hline \multicolumn{1}{|c|}{ Change Statistics } \\
\cline { 2 - 6 } & \multicolumn{1}{|c|}{$\begin{array}{c}\mathrm{R} \\
\text { Square } \\
\text { Change }\end{array}$} & $\begin{array}{c}\text { Chang } \\
\mathrm{e}\end{array}$ & $\mathrm{df1}$ & $\mathrm{df2}$ & \multicolumn{1}{|c|}{$\begin{array}{c}\text { Sig. F } \\
\text { Change }\end{array}$} \\
\hline $\begin{array}{r}688 \\
\mathrm{a}\end{array}$ & .474 & 38.691 & 2 & $86^{\mathrm{a}}$ & .000 \\
\hline
\end{tabular}

Hipotesis pertama yang menyatakan ada hubungan antara budaya organisasi dan kepuasan kerja terhadap motivasi kerja terbukti secara empiris dengan nilai korelasi ganda $\mathrm{R}$ sebesar 0,474 dan nilai $\mathrm{F}=38.691$; dengan $\mathrm{p}=0,000$. Nilai $\mathrm{p}<0,05$.

\section{Tabel 2. Hasil Uji Hipotesis Kedua}

\begin{tabular}{|c|r|c|c|c|c|c|}
\hline \multirow{2}{*}{$\mathrm{R}$} & \multicolumn{5}{|c|}{ Change Statistics } \\
\cline { 2 - 7 } & $\begin{array}{c}\mathrm{R} \\
\text { Square } \\
\text { Change }\end{array}$ & $\begin{array}{c}\mathrm{F} \\
\text { Chang } \\
\mathrm{e}\end{array}$ & $\mathrm{df1}$ & Sig. & $\mathrm{t}$ & Sig. \\
\hline .502 & .252 & 29.244 & 1 & .000 & 5.408 & .000 \\
\hline
\end{tabular}

Hipotesis kedua yang menyatakan bahwa ada hubungan positif antara budaya organisasi denagn motivasi kerja terbukti dengan nilai t sebesar 5.408, $\mathrm{p}=0,00$. Nilai tersebut menunjukan bahwa budaya organisasi yang ada di satlantas Polresta Sidoarjo memberikan pengaruh yang signifikan terhadap motivasi kerja anggota satlantas di Polresta Sidoarjo

\section{Tabel 3. Hasil Uji Hipotesis Ketiga}

\begin{tabular}{|c|r|r|r|r|r|r|}
\hline \multirow{2}{*}{$R$} & \multicolumn{5}{|c|}{ Change Statistics } \\
\cline { 2 - 7 } & $\begin{array}{c}\mathrm{R} \\
\text { Square } \\
\text { Change }\end{array}$ & $\begin{array}{c}\mathrm{F} \\
\text { Chang } \\
\mathrm{e}\end{array}$ & $\mathrm{df1}$ & Sig. & $\mathrm{t}$ & Sig. \\
\hline .545 & .297 & 36.811 & 1 & .000 & 6.067 & .000 \\
\hline
\end{tabular}


Psikologia (Jurnal Psikologi), Vol 2 (2), July 2017, 81-92

ISSN 2338-8595 (print), ISSN 2541-2299 (online)

Journal Homepage: http://ojs.umsida.ac.id/index.php/psikologia

DOI Link: 10.21070/psikologia.v2i2.1497

Hipotesis ketiga yang menyatakan ada hubungan positif antara kepuasan kerja dengan motivasi kerja terbukti dengan nilai $\mathrm{t}$ sebesar 6.067, $\mathrm{p}=0,00$. Nilai tersebut menunjukan bahwa kepuasan kerja yang ada di satlantas Polresta Sidoarjo memberikan pengaruh yang signifikan terhadap kerja anggota satlantas di Polresta Sidoarjo.

Anggota Satlantas dituntut tidak hanya melakukan aktivitas-aktivitas administrasi saja namun tidak jarang harus turun ke jalan sesuai dengan tugasnya. Sementara itu, dengan terus meningkatnya perbaikan sistem dan berbagai inovasi yang dilakukan untuk memberikan pelayanan yang optimal di bagian lalu lintas, anggota Satlantas harus menghadapi banyak tuntutan dari pimpinan maupun masyarakat. Kondisi tersebut membuat anggota satlantas menjadi kurang memiliki gairah dalam bekerja karena hasil kerja mereka tidak mendapat balasan yang setimpal. Menghadapi konflik tersebut dibutuhkan kepuasan kerja dan budaya organisasi yang baik untuk menjaga stabilitas dari motivasi kerja para anggota Satlantas.

Penelitian yang telah dilakukan oleh Diputra (2014) pada Hard Rock Hotel Bali dalam E-Jurnal Ekonomi dan Bisnis Universitas Udayana 3.5 (2014) : 276-288 menunjukan hasil bahwa Budaya organisasi berpengaruh positif dan signifikan terhadap motivasi kerja karyawan, hal ini berarti semakin tinggi kesesuaian antara budaya organisasi dengan karyawan dapat meningkatkan motivasi kerja karyawan, maka budaya organisasi dapat menjadi salah satu faktor yang meningkatkan motivasi kerja karyawan. Kepuasan kerja berpengaruh positif dan signifikan terhadap motivasi kerja karyawan, hal ini berarti bahwa semakin tinggi kepuasan kerja karyawan dapat meningkatkan motivasi kerja karyawan, maka kepuasan kerja dapat menjadi salah satu faktor yang meningkatkan motivasi kerja karyawan

Seperti yang diungkapkan oleh Robbins, (2002) bahwa apabila karyawan cocok dengan budaya organisasi di dalam suatu perusahaan tersebut maka akan meningkatkan motivasi kerja karyawan tersebut. Hal ini dikarenakan Sistem nilai dan keyakinan yang berlaku tempat kerja sangat mempengaruhi semangat yang merupakan salah satu wujud dari cermin motivasi kerja dalam suatu organisasi. Nilai-nilai dan keyakinan tersebut apabila diterima dengan baik maka akan menimbulkan kelekatan pada suatu organisasi yang pada akhirnya dapat meningkatkan motivasi kerja anggotanya.

Sistem nilai tukar atau tidak semata gaji namun berbagai hal yang diterima oleh 
Psikologia (Jurnal Psikologi), Vol 2 (2), July 2017, 81-92

ISSN 2338-8595 (print), ISSN 2541-2299 (online)

Journal Homepage: http://ojs.umsida.ac.id/index.php/psikologia

DOI Link: 10.21070/psikologia.v2i2.1497

individu ada nilai tukar non fisik seperti hubungan dengan rekan kerja, sikap atasan, kesenangan dengan pekerjaan itu sendiri dan jenjang karir yang berlaku pada organisasi. Kebutuhan secara fisik maupun non fisik haruslah terpenuhi agar para anggota memiliki kepuasan kerja yang tinggi dalam bekerja sehingga dapat meningkatkan motivasi kerjanya. Sesuai yang pendapat disampaikan oleh Siagian (1997) yaitu ada berbagai cara yang dapat dilakukan untuk meningkatkan kepuasan kerja karyawan, salah satunya dengan memberikan kebutuhan-kebutuhan karyawan agar motivasi kerja mereka menjadi meningkat.

Mengingat pentingnya motivasi kerja maka setiap organisasi maupun perusahaan akan berusaha meningkatkan meningkatkan motivasi kerja setiap anggotanya, tidak terkecuali di instansi Polri khususnya Satlantas. Motivasi kerja mampu menjadi suatu energi yang mengerakkan segala potensi, memunculkan keinginan yang tinggi untuk bekerja dengan baik. Pemberian motivasi dikatakan penting, karena motivasi sebagai suatu bentuk dorongan internal maupun eksternal dalam menunjang kinerja yang pada akhirnya akan menjadi faktor penentu dalam mewujudkan tujuan organisasi Hasil penelitian ini memberikan petunjuk yang bermanfaat yaitu untuk dapat meningkatkan motivasi kerja, yakni dengan cara memperbaiki sistem dan fasilitas yang ada.

\section{SIMPULAN}

Penelitian ini dilakukan pada anggota satlantas di Polresta Sidoarjo. Jumlah subjek penelitian ini adalah 89 orang. Seluruh subjek telah lama bekerja di bagian Satlantas Polresta Sidoarjo minimal 1 tahun dengan pangkat Bripda sampai dengan Aiptu dan memiliki tingkat pendidikan minimal SMA sederajat. Analisis data dilakukan dengan menggunakan teknik regresi. Hasilnya menunjukkan hubungan yang signifikan dari variabel budaya organisasi dan kepuasan kerja dengan motivasi kerja.

\section{DAFTAR PUSTAKA}

Alf, Crossman. (2003). "Job satisfaction and employee performance of Lebanese" Journal of Managerial Psychology Vol. 18 No. 4, 2003 pp. 368-376.

Arikunto, S. (2006). Prosedur Penelitian Suatu Pendekatan Praktek. Jakarta : PT. Rineka Cipta.

As'ad, M. (2004). Psikologi Industri, Seri Umum. Sumber Daya Manusia. Edisi 4. Yogyakarta : Liberty.

Diputra, Ida Bagus Gede Surya. (2014). Pengaruh Budaya Organisasi Dan 
Psikologia (Jurnal Psikologi), Vol 2 (2), July 2017, 81-92

ISSN 2338-8595 (print), ISSN 2541-2299 (online)

Journal Homepage: http://ojs.umsida.ac.id/index.php/psikologia

DOI Link: 10.21070/psikologia.v2i2.1497

Kepuasan Kerja Terhadap Motivasi Kerja Karyawan Pada Hard Rock Hotel BalI .E-Jurnal Ekonomi dan Bisnis Universitas Udayana 3.5 (2014) : 276-288

Handoko, T. Hani.(1997). Manajemen dan Sumber Daya Manusia. Yogyakarta: Penerbit Liberty.

Harris, S., Mossholder, K. (1996). The Affective Implications of Perceived Congruence with Culture Dimensions during Organizational Transformation. Journal of Management (JofM), 22(4), 527 547

Hasibuan, Malayu S. P., (1996), Manajemen Dasar, Pengertian dan Masalah, Edisi Kedua. Jakarta: PT. Toko Gunung Agung.

Jewell \& Siegall. (1998). Psikologi Industry/Organisasi Modern. Edisi 2. (Alih bahasa: Pudjaatmaka). Jakarta: Arcan.

Koesmono H, Teman. (2005). Pengaruh Budaya Organisasi Terhadap Motivasi dan Kepuasan Kerja serta kinerja Karyawan Pada Sub Sektor Industri Pengolahan Kayu Ekspor di Jawa timur. Disertasi. Universitas Airlangga Surabaya.

Mas'ud, Fuad. (2004). Survai Diagnosis Organisasional Konsep \& Aplikasi. Semarang: Badan Penerbit Universitas Diponegoro.

Moeljono, Djokosantoso. (2003). Budaya Korporat dan Keunggulan Korporasi. Jakarta : PT. Elex Media Komputindo.
.Munandar, A.S. (2011). Psikologi Industri dan Organisasi. Jakarta: Universitas Indonesia (UI-Press).

Molenaar, Keith, (2002), Corpoarte Culture, a Study of Firm With Outstanding Consideration Safety. Prosesional Safety pp 18-27

P. Siagian, Sondang. (1997). Manajemen Sumber Daya Manusia. Jakarta: PT. Toko Gunung Agung

Robbins, Stephen P, (1996). Perilaku Organisasi, konsep, Kontroversi, dan Aplikasi. Alih Bahasa :HAdyana Pujaatmaka. Edisi : Keenam. Jakarta : Penerbit PT. Bhuana Ilmu Populer.

Robbins, Stephen P. (2002). Prilaku Organisasi, Alih Bahasa Hadyana Pujaatmaka dan Benyamin Molan, Edisi Kedelapan, Jilid Kedua. Jakarta : Penerbit Prenhallindo.

Robbins P. Stephen, (2003). Teori Organisasi Struktur, Desain \& Aplikasi, Edisi 3, Jakarta : Penerbit Arcan.

Robbins, Stephen P. dan Mary Coulter. (2005). Management. 8th Edition. New Jersey : Prentice Hall.

Robbins, Stephen P. (2008). Organizational Behaviour, Tenth Edition (Perilaku Organisasi Edisi ke Sepuluh), Alih Bahasa Drs. Benyamin Molan. Jakarta : Salemba Empat. diterjemahkan oleh Sugeng Haryanto, Sukono Mukidi, dan M. Rudi Atmoko. Jakarta: Prenada.

Syahyuti. (2010). Defenisi, Variabel, Indikator dan Pengukuran dalam Ilmu Sosial. Jakarta: Bina Rena Pariwara. 
Psikologia (Jurnal Psikologi), Vol 2 (2), July 2017, 81-92

ISSN 2338-8595 (print), ISSN 2541-2299 (online)

Journal Homepage: http://ojs.umsida.ac.id/index.php/psikologia

DOI Link: 10.21070/psikologia.v2i2.1497

Winardi. (2002). Motivasi dan Pemotivasian dalam Manajemen. Jakarta: PT. Raja Grafindo Persada.

, (2012). Polisi Bermasalah Kapolda

Marah. Diakses pada 8 mei 2017 dari

http://www.surabayapagi.com/read/7

7990/2012/03/17/125_Polisi_Bermas

alah,_Kapolda_Marah.html. diakses

pada 8 Mei 2017 